\title{
Depression from a Different Perspective
}

\author{
Sefa Bulut*, Ishaq Ibrahim Hajiyousouf, Thseen Nazir \\ Department of Counseling Psychology, Ibn Haldun University, Istanbul, Turkey \\ Email: *sefabulut22@gmail.com
}

How to cite this paper: Bulut, S., Hajiyousouf, I. I., \& Nazir, T. (2021). Depression from a Different Perspective. Open Journal of Depression, 10, 168-180. https://doi.org/10.4236/ojd.2021.104011

Received: April 13, 2021

Accepted: September 21, 2021

Published: September 24, 2021

Copyright $\odot 2021$ by author(s) and Scientific Research Publishing Inc. This work is licensed under the Creative Commons Attribution International License (CC BY 4.0).

http://creativecommons.org/licenses/by/4.0/

\begin{abstract}
Depression is one of the most common yet a serious mental health condition that individuals have struggled with from the past to the present. It affects the functionality of a human being regardless of age, gender, ethnicity, or even religion. The aim of this article is to discuss depression in general and its Islamic perspective in specific as research has shown that an Islamically oriented approach and intervention works better with the Muslim population in general. The paper also aims to have a broader view of how Islam classified depression classically and its modern implications upon psychotherapy which also lets us explore the differences, similarities and gaps between the Islamic and Western perspectives of depression at large. A collection of both classic and modern sources was used to extract information and provide a scope of definitions and clarify what depression means from an Islamic perspective. It was found that application and integration of Islamically oriented psychotherapy showed a faster recovery in the Muslim clients. Yet, further studies and research needs to be conducted in order to compare the effectiveness among the religious and non-religious Muslims and to fill the gap as to why the Muslim population tends to be hesitant in seeking help regarding their psychological problems.
\end{abstract}

\section{Keywords}

Depression, Mental Health, Religion, Islam, Muslims, Psychotherapy

\section{Introduction}

Islam is the religion followed by more than 1.6 billion Muslims globally. It provides Muslims with ethics, values, and a behavioral code that can be highly beneficial in developing healthy coping mechanisms and adaptive strategies in order to deal with stressful and hard life events. Islam promotes harmony and believes in a balance or a golden mean. That's why it preaches harmony and also encourages finding solutions to worldly problems rather than relying just upon 
the promise of the afterlife. The Quran mentions, "Seek the life to come by means of what God granted you, but do not neglect your rightful share in this world. Do good to others as God has done well to you. Do not seek to spread corruption in the land, for God does not love those who do this" (Quran28: 77) (The Noble Qur'an, 1984: p. 526, Chapter 28, Verse 77).

Furthermore, Ibn Abbas reports that the Messenger of Allah said, "Take advantage of five before five: your youth before your old age, your health before your illness, your riches before your poverty, your free time before your work, and your life before your death." Narrated by Abdullah Ibn Abbas as mentioned in the book of Al-Dunyā (1995). Taking advantage of life could refer to maintaining well-being and high good mental health because in their absence a person cannot realize and fulfil his or her potential. That is why maintaining a good state of mental well-being can also be considered as an act of Ibadah. Mental health is optimal performance of mental functions in day-to-day life, resulting in productive day-to-day affairs, attaining satisfactory relationships, and the ability to adapt to change and cope with adversities in life. It refers to the overall well-being of an organism which includes cognitive, behavioural, and emotional well-being. Conditions such as stress more than one's optimal level, depression, and anxiety can have a profound effect and can destabilize one's state of mental health. There are many such issues and psychological disorders which can affect one's mental health but this paper focuses on depression from Islamic perspectives and we will try to zoom in from Islamic lenses.

Depression is an emotional state well known by all, but not experienced by everyone. It is a state that robs energy, and puts the victims in darkness and negativity, regardless of all the positive reasons to be happy. It is also beautifully defined by the great Muslim scholar Abu Zaid al-Balkhi (El-Belhi, 2012) in his book Mesalihul Ebdan vel Enfus as if it is a state of restlessness which can be explained as the extremist and the most profound state of sadness, while restlessness is like a burning flame, and sadness is like the embers that remain after this flame calms down. It is the most effective factor to exhaust the body, and it is like causing the forces of desire and motives of the soul in the disappearance of its luminosity.

Sadness or depression in the Arabic literature according to (Al-Dunya, 1991) can be explained as Ham which also comes in the plural as Humoom meaning Huzun or Ahzan which is sadness. Ham comes in a form of giving an emphasis or high importance to a thought above the others, and that is referred to as ihtimam, which as a result keeps the mind occupied, and that would lead to anxiety and sadness. Interestingly, ham and huzun are used for different situations yet both are expressed for sadness in general, as stated in the book that the difference is when the experience of discomfort is about something that may happen in the future tends to be called as ham. And when it is regarding a discomfort that happened in the past, it is called huzun. For example, the fear or worry of the individual about wasting time not worshiping his creator or falling into a 
sinful act sometimes in the future is ham. Whereas huzun is an actual sadness regarding a sinful act that was experienced in the past, which might be called as a feeling of guilt.

Huzun Sadness was mentioned in the Quran on forty-two occasions, and there is a connection between Huzun sadness and Khawf fear since fear is a concern about something that may happen in the future, and sadness is a concern about something that happened in the past, and both of them cause Qalaq anxiety (Buwoud, 2014). "Indeed, the believers, Jews, Sabians, and Christians whoever truly believes in Allah and the Last Day and does good, there will be no fear for them, nor will they grieve" (Quran5: 69) (The Noble Qur'an, 1984: p. 157, Chapter 5, Verse 69).

Meanwhile, individuals experience feelings such as high as happiness and low as sadness, and that is a component of human nature. But when sadness persists and continues for more than two weeks, it is known as clinical depression in the current time. Depression is considered as one of the most common problems, and according to (American Psychiatric Association, 2013) it is characterized by several symptoms. Those main symptoms are depressed mood most of the day, diminished interest or pleasure in all or almost all activities, significant weight loss without dieting or weight gain, insomnia or hypersomnia nearly every day, psychomotor agitation or retardation, fatigue or loss of energy, feelings of worthlessness or excessive or inappropriate guilt, diminished ability to think or concentrate, or indecisiveness, recurrent thoughts of death, and clinically significant distress or impairment in areas of functioning.

Park (2005) suggests that religions in general help people in finding meanings out of the incidents or experiences they have in their lives, especially on those challenging, painful, or very stressful occasions. Through religion, people tend to understand the surroundings and draw meaningful inferences that make them feel less stressed or in a better state. Religion allows individuals to change their pre-learned beliefs and goals that were disrupted, and bring them to an understanding that is more harmonized with their thoughts of the way they are experiencing in life. Therefore, religion is useful and effective means to help people reach a better and positive change during cases of experiencing a stressful event. During entire human history, religion, religious beliefs, religious dogmas evolved unmatching parallel with human existence. It played a pivotal role to stablize the life on earth and it had a huge impact in overall life of humans. Religious involvment is common and in our health-related issues, and it is playing a pivotal role. A survey conducted in 32 developing countries had showed that $92 \%$ of people accepted that religion is playing an important role in their lives (Crabtree \& Pelham, 2009). A large among of studies had suggested that religion plays an important role and may be used to cope with situations that are stressful. There are various other factors that are responsible for coping but religion also can play an important role in coping with stressful and life threatening situations (Auerbach et al., 2010). 


\section{Mental Health and Islam}

The attachment theory of John Bowlby (Bowlby, 1951) underscores that having a secure attachment style is linked to a person's overall well-being, better functioning, higher self-esteem, and greater coping along with healthy mental health outcomes. Similarly, a healthy attachment with God could also lead to better and increased mental functioning as the Quran mentions, “... And whosoever puts his trust in Allah, then He will suffice him..." (Quran65: 3) (The Noble Qur'an, 1984: p. 766, Chapter 65, Verse 3).

In the Medieval West, mental health conditions were thought to be from devils or demons which required exorcism as these were thought to be spirit-related problems. On the contrary, Medieval Muslim scholars acknowledged that mental illness was related to the physiological and psychological states of a human. Muslim scholars like Ibn Sina (known in the West as Avicenna) believed mental health conditions to be related to human physiology and psyche (Haque, 2004; Youssef, Youssef, \& Dening, 1996). In the golden era of Islam, Muslim scholars thoroughly discussed mental health and its effects on various aspects of life.

Al-Razi(known as Rhazes in the West) was the first Muslim physician that initiated the methods of psychotherapy and achieved enormous success in defining various mental health conditions and their symptoms. Such discussion on mental health is published in his book entitled 'El Mansuri' dan 'Al Tibb al-Ruhani' (Murad \& Gordon, 2002). This was a key reason for the establishment of the initial psychiatric ward in Baghdad, Iraq in 705 CE by al Razi (known as Rhazes in the West). This laid the foundation of the first psychiatric hospital in the world. As per Al-Razi's viewpoints, mental health conditions and disorders were, in reality, medical conditions that could be treated through drugs and by using psychotherapeutic methods (Murad \& Gordon, 2002).

\section{Depression \& Islam}

Islam has a key role in the life of Muslims to help in coping with negative life experiences and act as a protective factor to prevent and treat depression. Muslims are not immune to mental health conditions like depression and as such, seeking professional help is highly advised, just like in case of any other type of illness as the Quran mentions, "So, verily, with every difficulty, there is relief: Verily, with every difficulty, there is relief' (Quran94: 5-6) (The Noble Qur'an, 1984: p. 841, Chapter 94, Verse 5-6). Islam always encourages human to seek hope even when one has done the worst sins or faced with the deepest troubles as God's Mercy is always close. people to stay hopeful, even if someone has committed the worst sin or faced with most troublesome life event as there is always God's mercy, “And never give up hope of Allah's soothing Mercy: truly no one despairs of Allah's soothing Mercy, except those who have no faith" (Quran12: 87) (The Noble Qur'an, 1984: p. 316, Chapter 12, Verse 87). Furthermore, as God says: “And for those who fear Allah, He always prepares a way 
out, and He provides for him from sources he never could imagine. And if anyone puts his trust in Allah, sufficient is Allah for him. For Allah will surely accomplish His purpose: verily, for all things has Allah appointed a due proportion" (Quran65: 2-3) (The Noble Qur'an, 1984: p. 766, Chapter 65, Verse 2-3).

That is why Islam's compassionate nature and outlook should help us in remembering God in times of difficulty and hope from His Mercy and Compassion to ease the pain make it through. Even though Islam prohibits suicide and considers it as a major sin, yet the matter is not black and white, as we can acknowledge that a person with a mental health condition can have an impaired judgment and might not be totally capable of making the right decisions. Thus, he or she may not be held accountable for their action. God alone will judge the actions of people. Such an outlook can help us in reducing the guilt feeling which generally affects people with mental health conditions. Although it is reported that the Prophet did not pray at the funeral of a man who killed himself, he did not forbid his companions from praying at the man's funeral; this indicates a possibility for forgiveness.

Sadness and grieving are a part and parcel of human life. They form a natural reaction to the losses in life. Muslims believe that all suffering, happiness, death, and life are ordained by God. God is the source of strength and loss is a test from God of what meaning we create through our losses and suffering. The aim is to put our trust in God's Mercy. Such a belief is extremely helpful and comforting in the process of healing. For instance, close ones of the deceased are urged to be patient and accept God's will. The Quran says, 'Be sure we shall test you with something of fear and hunger, some loss in goods, lives and the fruits of your toil, but give glad tiding to those who patiently persevere. Who say, when afflicted with calamity: To Allah, we belong, and to Him is our return' (Quran2: 155) (The Noble Qur'an, 1984: p. 32, Chapter 2, Verse 155). People who have patience in accepting God's decree will be given a reward from Him. The Prophet Muhammad (pbuh) said: "No person suffers any anxiety or grief and says this supplication, but Allah will take away his sorrow and grief, and give him in their stead joy.

Having said that, however, Muslims are not immune to the feeling of grief or depression. And it is allowed to grieve and express sadness over the demise of a loved one. For example, when the Prophet's son, Ibrahim, died, the prophet said 'We are very sad for your death, O Ibrahim, Islam encourages Muslims to talk about and remember their loved one and recall the good deeds of their life. Prophet Muhammad (pbuh) himself never forgot his love for his beloved wife, Khadijah, even years after her death (Maqsood, 2002).

The noble Quran (2020) has placed high importance and paid great attention regarding the human soul, and has not left any aspect or topic regarding the soul without explanations. The Quran has approached the soul comprehensively in several occasions and situations, and to show the importance of the soul, the human soul was mentioned in two hundred and seventy-five verses and descrip- 
tions, this explains that human being must pay attention to the stability of their well-being and understand it in the most accurate way possible. Buwoud (2014) stated that the Quran talked about mental health, mental problems, the strength and weaknesses of the soul, how to reach a perfect state of the soul, and how to treat it when it is in a weak state. The Quran also mentioned the whispers, thoughts, emotions, and feelings such as happiness, sadness, anxiety, fear, and tranquility.

The prophet Mohammed (pbuh) was consoled by Allah SWT, to give him moral or emotional strength, and remove his distress and worry, after the revelation has been suspended for a long time, and people started to doubt his prophecy. After that, Surah Ad-Duhaa (The Morning Hours chapter) was revealed as an emotional support and as a relief from his sadness and hopelessnessand mention in the noble Quran; by the morning sunlight, and the night when it falls still; Your Lord (O prophet), has not abandoned you, nor he has become hateful of you; and the next life is certainly far better for you than this one; and surely your Lord will give so much to you that you will be pleased; did he not find you as an orphan then sheltered you? Did he not find you unguided then guided you? And did he not find you needy then satisfied your needs? So do not oppress the orphan; nor repulse the beggar, and proclaim the blessings of your Lord (Quran93: 1-11) (The Noble Qur'an, 1984: pp. 840-841, Chapter 93, Verse 1-11).

In another incident, the prophet Mohammed (pbuh) was consoled again for another incident, to encourage him to look at the positive side, since the prophet was preaching his people to believe in Islam, facing all the hardships and barriers were there to stop him from moving forward. As he was warning the people of Makkah that the way he is trying to make them accept is the right way, and he felt responsible for those who persist in not following the right path, and intentionally ignore what they are told. And because the prophet felt the responsibility for those people who persisted in their infidelity, he became sad and went into grieve worrying about the disbelievers for what will happen to them in the day of judgment, and then he was told by Allah to be thankful and be happy at least for those who followed him, and that he can pay his full attention to those who chose the right path. The believers should also be thankful for their guidance because they were promised with heaven, and that everyone is responsible for his actions, as it was mentioned in Sura Fatir; They will say: "Praise be to Allah (God) who has lifted sadness from us! Our Lord is forgiving, appreciative, the one who has settled us in the Everlasting Home because of His bounty. No toil will ever touch us there nor will any weariness affect us in it. The ones who disbelieved will have Hellfire. It will be neither finished off for them so that they may [really] die, nor will its torment be lightened for them. Thus we reward every [ingrate] disbeliever. They will scream away in it. "Our Lord, take us out! We'll act honorably, so differently from the way we have been acting!" Did We not let you live on and on so anyone who bears things in mind might remember (them) during its course? The Warner came to you. So have a taste! Wrongdoers 
will have no supporter (Quran35: 34-38) (The Noble Qur'an, 1984: p. 586, Chapter 35, Verse 34-38). When at time of calamity the prophet Mohammed (pbuh) used to make dua prayer and say; "O Allah, I am your servant, the son of your servant, the son of your maidservant. My forelock is in your hand, your command concerning me prevails, and your decision concerning me is just. I call upon you by every one of the beautiful names with which you have described yourself, or which you have revealed in your Book, or you have taught to any of your creatures, or which you have chosen to keep in the knowledge of the unseen with you, to make the Quran the delight of my heart, the light of my chest, and to remove my sadness and dispel my anxiety." (Sunnah, 2020).

\section{Treatment of Depression from an Islamic Prescpective}

A study was conducted by Mashitah \& Lenggono (2020), regarding Quranic recitation treatment and its impact on depression with patients who are going through hemodialysis treatment sessions. It was found out that by applying Quranic recitation to those patients while having the treatment, patients showed a clear reduction of depression rate, they also showed an improvement in the spiritual quality of their lives. Interestingly, the Quranic recitation throughout the medical treatment did not only reduce depression level but also had an effective reduction in anxiety levels.

Mental health is positively associated with religion in general in several studies, the importance of religion comes with a clear indication that religious individuals tend to have better outcomes not only in mental health but also in physical well-being. Chatters (2000) confirms that mental health and well-being have a positive direction and association with religion, meaning that the involvement of religion plays an important role, and it would result in a better consequence for religious individuals who are recovering from physical or mental illnesses.

Besides, Azhar \& Varma (2000) stated that by utilizing a developed or altered cognitive therapy with an addition of Islamic spirituality upon Muslim clients in a comparison study between applying the Islamic method and the normal method of cognitive therapy on anxiety and depression. It was found out that patients who went through the Islamic model of cognitive therapy showed much better results and faster improvement, in comparison to those who have gone through the non-modified cognitive therapy sessions. As Ferriss (2002) also documented in the study of religion and quality of life, that after the examination of the association between religion and quality of life, using two indicators such as life longevity as an objective measure, and happiness indicator as a subjective measure, and found out that there is a firm relationship between religion and length of life, he also added that there is also a positive association between religious individuals and happiness along with their satisfaction with life. Moreover, even though that psychotherapy such as cognitive behavioral therapy (CBT) seems to be effective in our modern time, yet there is a necessity to integrate religion in the process. As Hamdan (2008) mentions that Islam is an organized 
way of life in its comprehensive nature, Islam its-self came as guidance for many aspects of life, such as economy, social, family, spirituality, and so on, it plays a central factor that covers life aspects for Muslims. Therefore, there must be an integration between modern psychotherapy and Islamic teachings for Muslim clients, or at least in the initial stages of psychotherapy. The integration of religion can play an important factor in the process of treatment. In an experiment that was conducted by (Azhar \& Varma, 1995), an assembly of 32 depressed patients was divided into two groups, the study, and the control group. For the study group, there was an addition of 15 to 20 sessions of integration of religious perspective, while for the control group there was no addition of religious perspective. The patients in the study group showed faster improvement in the initial 3 months of treatment in comparison to the control group.

Another example of integration was discussed by (Thomas \& Ashraf, 2011) that we can also find similarities between the concepts of cognitive-behavioral therapy and Islamic teachings. As Beck introduced that individuals may develop core believes as a result of unfortunate childhood experiences, the individuals tend to form dysfunctional thoughts, assumptions, and attitudes towards the world around them. Those past formed beliefs and attitudes may work as a trigger for individuals and may also affect their present and future. Therefore, it is mentioned in the Islamic teachings that the servant of God must also have an understanding of Husn al-Dhan, which is referred to as having a good or positive opinion. In general, Islam encourages Muslims to be always having a positive attitude toward God, society, and the future, since the absence of Husn al-Dhan good opinion is just as similar as the term dissonance in cognitive therapy.

Moreover, Buwoud (2014) suggests that treatment of depression or even prevention of depression in Islam can be achieved through following several methods or tools, such as following the Islamic principles, piety or good deeds, worship, patience, prayers, and remembrance of God, satisfaction, and contentment with whatever we have, repentance, prioritizing positive thinking, knowing how to behave with toxic people, and having hope. Following the Islamic principle means, believing in Qaeda and Qadar the predestination of things, believing in the hereafter, believing in the names of Allah SWT, and understanding the meaning of calamity and depression based on faith. To explain, believing in the predestination of things means that a Muslim should have a strong relationship with his Creator, to have a life without anxiety or sadness, a true believer has no fear in this world life, since he knows that there is no harm or calamity will happen to him without Allah's Will, and whatever good will happen to him, it will also be in the Will of Allah SWT, Surely those who say, "Our Lord is Allah," and then remain steadfast - there will be no fear for them, nor will they grieve $(\mathrm{Qu}$ ran46: 13) (The Noble Qur'an, 1984: pp. 682-683, Chapter 46, Verse 13) and Say, "Nothing will ever befall us except what Allah has destined for us. He is our Protector." So in Allah let the believers put their trust" (Quran9: 51) (The Noble 
Qur'an, 1984: p. 252, Chapter 9, Verse 51).

Besides, believing in the hereafter is also meant understanding that this worldly life is just very short when the believer acknowledges and accepts that there is a hereafter he will less likely be attached to life and would not be very depressed in this life when he loses something he loves, the prophet PBUH said; "Were this world worth a wing of a mosquito, He would not have given a drink of water to an infidel." (Sunnah, 2020). The application of integration of psychotherapy with religion can be effective. For example, some methods such as praying may work as effectively as meditation. As Azhar \& Varma (1995) suggest that praying may play an effective role for those suffering from depression, because praying creates the same feeling of meditation, which generates relaxation of the body, reducing tension and elevating well-being and mental health in general. Meditation exercises help in concentration, increasing consciousness, enabling individuals to control their thoughts and feelings. Thereby, worship is a form of meditation that is having religious features and that would provide the same results.

El-Belhi (2012) in the Islamic tradition has also talked about ways and techniques that help sustain a healthy body and soul in his book the sustenance of body and soul. Some of the topics discussed in the book were, the importance and the amount an individual needs to regulate the interests of the soul, regulations regarding protecting the health of the soul, regulations regarding regenerating the health of the soul if it is lost, identifying the concepts and how the symptoms of the soul are defined, and dealing with and controling depression and anxiety.

Regarding the importance of the sustenance of the health of the soul, he said that as it is important to know how to manage the body if it is there, and regenerate it if it was missing in terms of physical sickness which can be observed by others, it is important to use medicine and control the diet to keep health or retrieve it in time of sickness. As the individual is vulnerable to have physical sicknesses and symptoms we refer to as fever, headaches, and several other symptoms, we can also say that the individual could also have psychological symptoms such as anger, anxiety, depression, and hopelessness and that those physical symptoms can disappear one after another through time, the psychological symptoms are hard to disappear, since a human being is always vulnerable in his life to a stimulus that evokes anger, sadness and anxiety all the time. These psychological symptoms are hard to fully disappear since every individual would experience them with different intensity, for example, some may feel sad, scared, or helpless because something may seem normal, while some others may be resilient in the same situation. Therefore, the individual must know and understand his weaknesses and strength, provide the necessary care for his soul to keep it healthy and avoid whatever leads to anxiety and causes distress.

Secondly, El-Belhi (2012) also discussed regulations regarding protecting the 
health of the soul. As it is required for the individual to protect his physical health, maintain its strength, and treat it if it is an unhealthy state, by protecting it from external factors, such as heat and cold, regulation of diet, using whatever is beneficial for the body and eliminating whatever causing the sickness. It is also advised that the individuals should maintain the health of the soul by avoiding the negative external factors such as, avoiding and blocking whatever causes the heart to be agitated and unpeaceful, and individuals should keep a distance from whatever they may hear or see things that may cause distress and lead to anxiety, sadness, anger, fear, and disturbing thoughts.

Thirdly, he also added and discussed regulating or regenerating the health of the soul if it is lost. As it is advised that when an individual is having physical symptoms, pain, or disease, the individual would do anything to stop the complaints, by utilizing medicine, refusing to eat whatever could be a cause of the disease, and by eating or drinking what is healthy. In the meantime, the health of the soul is also an important aspect and should be looked at as much as physical health. Mental health can be gained back through spirituality, the soul can be treated through internal and external factors, the individual can internally heal himself by using the power of thought to be as calm as possible, a person should keep all his thoughts that cause the distress under control. Additionally, and externally can be by the support of someone else, a person can feel better if he receives counseling or advice from someone who had experienced something similar in life and faced difficulties but he reached a healthy state of the soul. Additionally, he also talked in details regarding identifying the symptoms of sicknesses of the soul, defining that the concepts are important. In order to combat the sickness of the soul, it is necessary to identify the strong parts of the soul which is virtuous, such as the mind, understanding, and memory and whatever that may come as opposed to that, and there are also good ethics or manners, such as generosity, chastity and hospitality, and the opposite side can be anger, fear and so on and how they could affect the soul. Those negative parts can be considered as normal symptoms such as fear, but when they become severe, they may reach anxiety that affects the soul.

Finally, Elbelhi discussed dealing with and controlinng depression and anxiety, he emphasized the importance of depression as a topic that requires full attention, since they have an extremely negative effect on the human soul and heart since depression is the most intense level of sadness, it causes impairment in the life of the depressed individuals, leading them to helplessness and despair, disallowing them from having pleasure from anything including the ones they used to enjoy. Treatment of depression that is experienced without an apparent reason can be achieved through several ways, such as talking to someone, establishing honesty and sincerity, trying to find happiness in things useful for the soul, and hearing whatever beautiful to the ear such as music that would help to relieve the soul from its sorrow. On the other hand, treatment of depression that is with clear apparent reason such as loss of loved ones, or failure to achieve a specific goal, 
can be treated externally by receiving advice from a knowledgeable person, and internally by controlling the thoughts and bearing in mind what depression is and understanding its consequences.

\section{Conclusion}

Depression is an age-old phenomenon in Human history. Around the world, Muslim scholars had classified it centuries before the Western scholars did and tried to treat it with different approaches. No doubt, Modern psychology has progressed enormously, and there are piles of research done in the field but it can learn profound lessons from Islamic concept of depression and Islamic approaches to depression. Understanding the Islamic approach to depression is essential as research has found that the majority of Muslims are hesitant to seek mental health help from professionals in the Western nations (Hedayat-Diba et L., 2014; McGoldrick et al., 2005) and due to the differences in their beliefs and lack of understanding of the Islamic principles on the part of the therapists or professionals in their modalities. Both front therapist and client need to understand the religious perspective to it as religion plays a profound role in the therapeutical approach among Muslims. Many Muslims might be uncomfortable in seeking help concerning mental health to avoid any conflicts with their established religious beliefs. That is why psychotherapists and counselors can also consider using certain spiritually modified cognitive behavioral therapy techniques, by using techniques drawn from the Islamic contexts rather than merely Western cognitive-behavioral therapy (Azhar \& Varma, 2000; Wahass \& Kent, 1997).

It is also important to note that there are weaknesses and gaps in the studies that try to apply the Islamically modified or oriented counseling treatments since implementing the Islamic method might be effective for those who are committed to Islam. Hamdan (2008) states that there are Muslim clients who are non-religious, and they may have a problem in the process of the therapy sessions since they are not willing to discuss such issues, which may lead to distressing situations. More studies in depth may be required to find out how to deal with such situations and how to approach patients by integrating Islamic principles in the most suitable way possible.

In nutshell, the aim is not to prove which approach is better but to help client do deal with the problems. If the client is a staunch believer and religion had a huge role in his life then the therapist must be equipped with the religious approaches. It may enhance the effectiveness of therapy and on another side, it may help to eradicate the reluctance towards therapy as it had been seen in many cultures.

\section{Conflicts of Interest}

The authors declare no conflicts of interest regarding the publication of this paper. 


\section{References}

Al-Dunya, I. A. (1991). Alham wa Alhuzun [Anxiety and Sadness] (1st ed.). Dar Al Salam for Printing, Publishing, Distribution \& Translation.

Al-Dunyā, I. A., \& M. Yousouf (1995). Shortness of Hope (1st ed., Vol. 1, pp. 87-90). Dar Ibn Hazm.

American Psychiatric Association (2013). Diagnostic and Statistical Manual of Mental Disorders DSM-5 (5th ed.). American Psychiatric Publishing. https://doi.org/10.1176/appi.books.9780890425596

Auerbach, R. P., Abela, J. R., Zhu, X., \& Yao, S. (2010). Understanding the Role of Coping in the Development of Depressive Symptoms: Symptom Specificity, Gender Differences, and Cross-Cultural Applicability. British Journal of Clinical Psychology, 49, 547-561.

Azhar, M. Z., \& Varma, S. L. (1995). Religious Psychotherapy in Depressive Patients. Psychotherapy and Psychosomatics, 63, 165-168. https://doi.org/10.1159/000288954

Bowlby, J. (1951). Maternal Care and Mental Health (Vol. 2). World Health Organization.

Buwoud, A. (2014, December). Aleilaj Alnafsi lil-Idhtirabaat Al-Nafsiyah Min Manzur Islami-Al-Ikti'aab Namudhaj [Psychotherapy for Mental Disorders from an Islamic Perspective-Depression for Instance]. Social Sciences Journal, No. 19, 199-209.

Chatters, L. M. (2000). Religion and Health: Public Health Research and Practice. Annual Review of Public Health, 21, 335-367.

https://doi.org/10.1146/annurev.publhealth.21.1.335

Crabtree S, Pelham B. (2009). World Gallup Poll: Religion Provides Emotional Boost to World's Poor. The Gallup Poll.

El-Belhi, E. Z. (2012). Mesalihu'l-Ebdan Ve’l-Enfüs Beden ve Ruh Sağllğı (2012 ed.). Türkiye Yazma Eserler Kurumu Başkanlığı Yayınları.

Ferriss, A. L. (2002). Religion and the Quality of Life. Journal of Happiness Studies, 3, 199-215. https://doi.org/10.1023/A:1020684404438

Hamdan, A. (2008). Cognitive Restructuring: An Islamic Perspective. Journal of Muslim Mental Health, 3, 99-116. https://doi.org/10.1080/15564900802035268

Haque, A. (2004). Psychology from Islamic Perspective: Contributions of Early Muslim Scholars and Challenges to Contemporary Muslim Psychologists. Journal of Religion and Health, 43, 357-377. https://doi.org/10.1007/s10943-004-4302-Z

Hedayat-Diba, Z., Richards, P., \& Bergin, A. (Eds.) (2014). Handbook of Psychotherapy and Religious Diversity. American Psychological Association.

Maqsood, R. (2002). After Death Life: Thoughts to Alleviate the Grief of All Muslims Facing Death. Talha Publication.

Mashitah, M., \& Lenggono, K. (2020). Quran Recitation Therapy Reduces the Depression Levels of Hemodialysis Patients. International Journal of Research in Medical Sciences, 8, 2222-2227. https://doi.org/10.18203/2320-6012.ijrms20202271

McGoldrick, M., Giordano, J., \& Garcia-Preto, N. (Eds.). (2005). Ethnicity and Family Therapy. Guilford Press.

Murad, I., \& Gordon, H. (2002). Psychiatry and the Palestinian Population. Psychiatric Bulletin, 26, 28-30. https://doi.org/10.1192/pb.26.1.28

Park, C. (2005). Handbook of the Psychology of Religion and Spirituality. The Guilford Press.

Razali, S. M., Hasanah, C. I., Aminah, K., \& Subramaniam, M. (1998). Religious-Soci- 
ocultural Psychotherapy in Patients with Anxiety and Depression. Australian \& New Zealand Journal of Psychiatry, 32, 867-872.

https://doi.org/10.3109/00048679809073877

Sunnah (2020, December 25). Hisn al-Muslim 120-Fortress of the Muslim (Hisn al-Muslim) - حصن المسلم-Sunnah.com-Sayings and Teachings of Prophet Muhammad (صلى الله عليه و سلم). https://sunnah.com/hisn:120

The Noble Qur'an (1984). Translation of the Meanings of The Noble Qur'an in the English Language (M. T.-u.-D. AI-Hilali, \& M. M. Khan, Trans.). King Fahd Complex for the Printing of the Holy Qur'an. Retrieved 2021.

The Noble Quran (2020, December 15). https://quran.com/

Thomas, J., \& Ashraf, S. (2011). Exploring the Islamic Tradition for Resonance and Dissonance with Cognitive Therapy for Depression. Mental Health, Religion \& Culture, 14, 183-190. https://doi.org/10.1080/13674676.2010.517190

Wahass, S., \& Kent, G. (1997). Coping with Auditory Hallucinations: A Cross-Cultural Comparison between Western (British) and Non-Western (Saudi Arabian) Patients. The Journal of Nervous and Mental Disease, 185, 664-668. https://doi.org/10.1097/00005053-199711000-00002

Youssef, H. A., Youssef, F., \& Dening, T. (1996). Evidence for the Existence of Schizophrenia in Medieval Islamic Society. History of Psychiatry, 7, 55-62.

https://doi.org/10.1177/0957154X9600702503 